\title{
A Three Year Retrospective Analysis of Anti-Tnf Treatment Outcomes in Rheumatoid Arthritis and Ankylosing Spondylitis Patients
}

\section{Romatoid Artrit ve Ankilozan Spondilitli Hastalarda Anti-Tnf Tedavisi Sonuçlarının Üç Yıllık Retrospektif Analizi}

\author{
Dilek Tezcan', (D) Seyfettin Üstünsoy², (i) İrem Bilgetekin4, (Döksal Keskin³ \\ 'Ankara Dışkapı Yıldırım Beyazıt Research and Education Hospital, Department of Rheumatology \& Immunology, Ankara, Turkey. \\ ${ }^{2}$ Special Silivri Medicalpark Hospital, Department of Central Laboratory, İstanbul, Turkey. \\ ${ }^{3}$ Ankara University School Of Medicine, Department of Immunology And Allergy, Ankara, Turkey \\ ${ }^{4}$ Ankara Research And Education Hospital, Department of Medical Oncology, Ankara, Turkey
}

Öz

Amaç: Ankilozan Spondilit (AS) ve Romatoid artrit(RA)'lı hastalarda Anti-TNF alfa tedavisinin etkinliğini ve güvenirliğni araştırmak.

Gereç ve Yöntem: Çalışmamız retrospektif bir çalışma olup, bu çalışmada Romatoloji-İmmunoloji Bilim Dalı Polikliniğine 2009 ile 2011 tarihleri arasında başvurmuş 18-65 yaşları arasında 1987 American Rheumatism Association kriterlerine göre RA tanısı almış ve Anti-TNF alfa tedavisi almakta olan 110 hastanın, 1984 Modifiye New York Kriterleri' ne göre AS tanısı almış ve Anti-TNF alfa tedavisi almakta olan 70 hastanın dosyaları ve ilgili formları incelendi. Bu hastalardan 100 RA hastası (76 kadın, 24 erkek),60 AS hastası (16 bayan,44 erkek) çalışmaya alındı. Çalışmaya alınan hastaların Anti-TNF alfa tedavisine yanıtları (klinik parametrelerden BASDAI, DAS28 ve VAS skoru; laboratuvar parametrelerinden Sedimentasyon ve CRP düzeyleri) tedavi öncesi ve tedavi sonrası altıncı ayda karşılaştırılarak değerlendirildi.

Bulgular: Anti-TNF alfa tedavisi öncesi ve tedavinin 6. ayındaki AS için BASDAi skoru, RA için DAS28 skoru, her iki hastalık için VAS, Sedimentasyon ve CRP düzeyleri istatistiksel olarak anlamlı düzelme göstermiş olup demografik verilerin bu değerleri etkilemediği saptanmıştır.

Sonuç: Bulgularımız Anti-TNF alfa tedavisinin AS ve RA hastalarında çok etkili olduğu ve güvenle kullanılabileceğini göstermektedir. Bu bulgular çalışmanın kısa dönem sonuçları olup, çalışma sonuçlarının geçerliliğini ortaya koymak için daha geniş hasta serilerinin yer aldığı, uzun takip süreli çalışmalara ihtiyaç vardır.

Anahtar Kelimeler: Ankilozan spondilit; romatoid artrit; Anti-TNF alfa tedavisi; tedavi sonuçları

\begin{abstract}
Objective: To investigate the effectiveness and reliability of Anti-TNF alfa treatment in Ankylosing Spondylitis-Rheumatoid arthritis patients.

Material and Method: 180 patients (110 Rheumatoid arthritis (RA) patients diagnosed according to 1987 American Rheumatism Association criteria, 70 Ankylosing Spondylitis (AS) patients diagnosed according to Modified NewYork Criteria) admitted to the hospital for arthritis and related compliants who were followed up and treated with Anti-TNF alfa treatment in the department of Rheumatology\&Immunology from 2009 to 2011. We enrolled 100 patients with RA (76 women, 24 men) and 60 patients with AS (16 women, 44 men) to the study, excluded 20 patients according to the exclusion criteria. The response of the patients to the Anti-TNF alfa treatment was evaluated by comparing the clinical parameters BASDAI, DAS28 and VAS score; and laboratory measurements of erytrocyte sedimentation rate, $\mathrm{C}$-reactive protein levels of rheumatoid arthritis and ankylosing spondylitis before and at the sixth month of the treatment.

Results: After the sixth month of Anti-TNF alfa treatment, BASDAl score for AS, DAS28 score for RA, VAS, ESR and CRP levels for both diseases showed a statistically significant improvement, moreover demographic variations did not affect these values.

Conclusion: Our results demonstrated that Anti-TNF alfa treatment is safe and effective treatment modality in AS and RA patients. These findings are short-term results of our study; however, future studies with larger patient series and long term follow-up are needed to confirm outcomes of long term Anti-TNF alfa therapies.
\end{abstract}

Keywords: Ankylosing spondylitis; rheumatoid arthritis; Anti-TNF alfa treatment; outcomes 


\section{INTRODUCTION}

Rheumatoid arthritis (RA) and Ankylosing Spondylitis (AS) are both chronic, inflammatory, progressive, autoimmune rheumatismal disorders usually presents with arthritis. The etiology and pathogenesis of them are not totaly clarified yet, but previous studies obviously showed that many triggering factors take part at the initial stages of diseases including environmental factors, genetic tendencies, hormonal abnormalities and some viral/bacterial infections. NSAIDs (nonsteroidal anti-inflammatory drugs) are the most commonly used first step medications for the treatment, besides that immunosupressive agents also take place in the treatment regimens. ${ }^{[1,2]}$

$\mathrm{RA}$ is an inflammatory polyarthritis which ranging from mild symmetrical synovitis to the treatment refractory, agressive and severely patient disabling form. The most important characteristics of the disease is the symmetrical synovial proliferation and sensitivity at the small joints of feet and hands. Early diagnosis and treatment is very important at RA patients, because disease leads to severe joint damage and disability in a short time period. AS is one of the most common chronic inflammatory joint diseases. It effects mainly the spine, however it may also involve peripheral joints and extra-articular structures. AS leads to ankylosis of vertebral and sacroiliac joints. Pain, morning stiffness and functional disability are the most prevalent presenting complaints..$^{[1,2]}$

TNF alpha (TNFa) is a cytokine which is released from active macrophage and fibroblasts. Its potential role in inducing and maintaining inflammatory proliferative processes in rheumatoid synovitis was shown by previous studies. The reasons behind the evaluation of TNF as the target molecule in the RA treatment is mainly based on three facts:

1. TNFa concentrations were detected high in synovial fluids of patients with RA.

2. In vitro studies revealed that TNFa induces the other inflammatory cytokines and chemokines in synovial cytokine network.

3. In in-vivo experimental models arthritis were supressed with anti TNFa agents. ${ }^{[3]}$

When synovial fluid and synovial tissue of RA patients have been compared with that of osteoarthritis patients (OA); it has been observed that TNFa mRNA transcription and protein secretion were higher in RA group than OA group. Another evidence indicating the importance of TNFa in the pathogenesis of RA is that TNFa receptors are localized in cartilage-pannus junction where pathological erosions arise most commonly in these regions. Moreover, after the TNFa targeted treatment plasma inflammatory biomarkers and the number of circulating regulatory $T$ cells decreased, the bone erosions radiologically and ultrasonographically regressed, clinical symptoms and disease activity reduced. ${ }^{[4-7]}$ Likewise, TNFa levels were found to be high in the sacroiliac joint biopsy materials of AS patients. ${ }^{[7]}$ After the initiation of Anti-TNF alfa atment on AS patients a prominent clinical status improvement and marked increase in the life quality was observed. ${ }^{[8,9]}$ Moreover recent studies showed that TNFa mRNA level were high in sacroiliac joint fluid as well. ${ }^{[10]}$ These findings suggest that TNFa plays a a central role in the pathology of cartilage and bone erosions and inflammation developing in spondyloarthropathies, and also these findings clearly demonstrates the role of TNFa in the pathogenesis of RA and $A S^{[8,9]}$

It is thought that in cases with $A S$, both in peripheral blood and in lamina propria of colon, Th1 cytokine [IL-2 and interferon gamma (IFNY)] expression is impaired, owing to harmful effect of high TNF concentrations on the production of IL-2 and INF production by T cells, and that chronic inflammation and auto immunity arises as a consequence of the impairment of defence against bacteria by T cells in intestines. ${ }^{[11,12]}$

Current treatments used in RA and AS include NSAIDs, glucocorticoids, disease modifying anti-rheumatic drugs (DMARDs) and TNFa inhibitors. Although DMARDs used in RA and AS treatment are effective, disease activity still can not be controlled completely in many patients. They may remain ineffective particularly in AS patients with axial involvement. New developments in the treatment of RA and AS, have provided alternative treatment regimes targeting cytokines such as TNFa, which play key role in pathogenesis, in patients refractory to conventional treatment. Satisfactory results have been obtained with Anti-TNF alfa drugs in patients refractory to conventional treatment and the progress of radiological damage can be prevented.

\section{MATERIAL AND METHOD}

This retrospective study was conducted at Rheumatology Immunology Department of Ankara Dışkapı Training and Reseach Hospital between 2009-2011. 115 patients files who were diagnosed with RA according to 1987 American Rheumatism Association Criteria receiving Anti-TNF alfa treatment and 70 patients who were diagnosed with AS according to 1984 Modified New York Criteria receiving Anti-TNF alfa treatment were enrolled to the study. Of these patients, according to the inclusion and exclusion criterias, 100 RA patients and 60 AS patients were included in the study. Sociodemographic and clinical characteristics were recorded. The drugs used by the patients, drug doses, duration of drug use, other accompanying diseases and history of smoking were inquired. Patients were evaluated with clinical and laboratory parameters before and after treatment.

Applied drug doses were as follows: methotrexate $10-25 \mathrm{mg} /$ weeks; leflunomid $20 \mathrm{mg}$ /day; sulfasalazine $2 \mathrm{gr} /$ day, infliximab at $0,2,6$. weeks and then every 8 weeks; adalimumab every two weeks and etanercept twice weekly. All patients also used analgesics, NSAIDs and methylprednizolone 4-16 mg/day in addition to those drugs.

Male and female patients between the ages of 18-65, patients diagnosed with AS according to 1984 Modified New York Criteria, patients who have discontinued treatment after three months of using sulfasalazin it due to lack of response and/or side effects, and those diagnosed with RA according to 
Criteria of American Rheumatism Association, and who used at least two NSAIDs at maximum dose at least for 3 months and discontinued treatment due to lack of response or side effects, and patients with disease activity (BASDAI) score $>4$ were included in the study.

Patients with previous or active tuberculosis, patients with active infection, and high risk of infection (septic arthritis or prosthesis infection within the last 12 months, ,persistent or recurrent lung infection, permanent urinary catheter), patients who are pregnant or lactating, or do not use effective birth control method, and those with lupus and demyelinating diseases and patients with malignant diseases were excluded from the study.

In the evaluation of functional status and disease activity, for RA patients, disease activity score (DAS28), for AS patients Bath AS Disease activity Index (BASDAI), for both diseases VAS (Visual Analog Scale ) scoring was used. ${ }^{[13]}$ If BASDAI score was $\geq 4.1$, it was considered as activation of disease. ${ }^{[3]}$ DAS28>5.1 was evaluated as high disease activity and DAS28<2.6 as low disease activity. .

Eritrocyte sedimentation rate (ESR) and CRP (C reactive protein) were measured by automatic analysers. Sedimantasyon rate was measured with Westergreen method (Lena ESR analyzer, Lınear Chemıcals S.L, Spaın) and CRP with turbidometric method (Cobas 6000, Roche Diagnostics).

Analysis of data was carried out with SPSS for Windows 11.5 software program. Continous variables was investigated with Shapiro Wilk test whether they are normallly distributed. Descriptive statistics and continuous variables were expressed as mean \pm standard deviation or median (minimum-maximum), and categorical variables with the number of cases and percentages (\%). The significance of the difference between groups was evaluated with Student's $t$ test in mean values and the significance of the difference between groups was evaluated with Mann Whitney $U$ test in median values. Categorical parameters were analysed with Pearson's chi-square or Fisher's exact chi-square test. Whether there was a difference in groups between pre and post treatment measurements was investigated with Wilcoxon rank test. Whether there was a statistically significant correlation between continuous variables was investigated with Spearman's Correlation test. $\quad \mathrm{P}<0.05$ was considered statistically significant.

\section{RESULTS}

\section{Demographic Data}

160 patients receiving Anti-TNF alfa treatment were included in this study. (100 RA patients, 60 AS patients). Anti-TNF alfa treatment included infliximab, etanercept and adalimumab. Majority of patients used methotrexate, sulfasalazine, methylprednisolone, NSAIDs along with AntiTNF alfa treatment. In addition, there were 73 patients taking chloroquine and 27 patients using leflunomid instead of methotrexate.
In RA group 24 males and 76 females were included in the study. Mean age of patients receiving Anti-TNF alfa treatment was $47.7 \pm 12.5$ years. Mean age of diagnosis with RA was $37.5 \pm 10.7$ years. Mean duration of disease was found to be 8.5 years (range: 1-25 years) in RA patients receiving Anti-TNF alfa treatment, and mean duration DMARDs treatment was 8 years (range: 1-19 years). The percentages of Anti-TNF alfa drugs used in RA patients group was 37\% (n:37), 20\% (n:20) and 43\% ( $n: 43$ ) infliximab, etanecercept and adalimumab respectively. Mean doses of methotrexate, sulfasalazin, NSAIDs and steroid used in conjunction with Anti-TNF alfa drug treatment were similar in all patients (Table 1).

\begin{tabular}{lccc}
\hline \multicolumn{3}{l}{ Table 1. Demographic and clinical features of study population } & \\
& AS (n=60) & RA (n=100) & p-value \\
\hline Age (year) & $39,3 \pm 11,5^{* * *}$ & $47,7 \pm 12,5$ & $<0,001$ \\
Gender & & & $<0,001$ \\
$\quad$ Male & $44(\% 73,3)^{* * *}$ & $23(\% 23,0)$ & \\
$\quad$ Female & $16(\% 26,7)^{* * *}$ & $77(\% 77,0)$ & \\
Age at disease onset & $29,2 \pm 10,6^{* * *}$ & $37,5 \pm 10,7$ & $<0,001$ \\
Duration of disease & $8(1-35)$ & $8,5(1-25)$ & 0,155 \\
Duration of DMARDs usage (year) & $5(1-30)^{* *}$ & $8(1-19)$ & 0,010 \\
Smoking history & $29(48,3)^{* * *}$ & $15(\% 15,0)$ & $<0,001$ \\
Anti-TNF alpha treatment regimen & & & $<0,001$ \\
\multicolumn{1}{c}{ Adalimumab } & $8(\% 13,3)^{* * *}$ & $43(\% 43,0)$ & \\
$\quad$ Etanersept & $12(\% 20,0)^{* * *}$ & $20(\% 20,0)$ & \\
$\quad$ Infliksimab & $40(\% 66,7)^{* * *}$ & $37(\% 37,0)$ &
\end{tabular}

RA: Rheumatoid arthritis; AS: Ankylosing spondylitis; DMARDs: Disease-Modifying Anti rheumatic Drugs; TNF: Tumor Necrosis Factor. Significance levels are shown as ${ }^{*} p<0,05,{ }^{* *} p<0,01, * * * p<0,001$ when comparing ankylosing spondylitis patients and rheumatoid arthritis patients. Data are presented as mean $\pm \mathrm{SD}$ (standard deviation) and percentages.

60 AS patients included in the study (44 male and 16 female). Mean age of AS patients receiving Anti-TNF alfa treatment was $39.3 \pm 11.5$ years. Mean age of diagnosis with AS was $29.2 \pm 10.6$ years. Among AS patients receiving Anti-TNF alfa treatment, mean duration of disease was 8 years (range:1-35 years), and mean duration of DMARDs usage was 5 years (range:1-30 years). The percentages of Anti-TNF alfa drugs used in AS patients group was $66.7 \%$ (n:40), 20\% (n:12) and $13.3 \%$ (n:8) infliximab, etanecercept and adalimumab respectively. Mean doses of methotrexate, sulfasalazine, NSAID and steroid used in combination with Anti-TNF alfa were similar in all patients (Table 1).

According to our study results a statistically significant difference was found between RA and AS patients using DMARDs and Anti-TNF alfa treatment in terms of age, sex and the age of diagnosis (respectively $p<0.001, p<0.001, p<0.001$ ). In addition no significant difference was found between RA and AS patients using DMARDs and Anti-TNF alfa treatment in terms of disease and DMARDs usage duration (respectively p:0.155, p:0.11). Mean dose of methotrexate, sulfasalazine, NSAIDs and steroid used by patients in combinatin with AntiTNF alfa treatment was similar in all groups (Table 1). 27 AS patients and 46 RA patients had comorbid diseases, namely HT(hypertension), DM(diabetes mellitus), HL(hyperlipidemia), osteoporosis, anemia and goitre (Table 2). 


\begin{tabular}{lcc}
\multicolumn{3}{l}{ Table 2. Distribution of co-morbid diseases according to the patient groups } \\
\hline \multicolumn{1}{l}{ AS $(\mathbf{n}=\mathbf{6 0})$} & RA (n=100) \\
\hline Co-morbid diseases & $27(\% 45,0)$ & $46(\% 46,0)$ \\
HT & $13(\% 21,7)$ & $28(\% 28,0)$ \\
DM & $1(\% 1,7)$ & $3(\% 3,0)$ \\
HPL & $20(\% 33,3)$ & $34(\% 34,0)$ \\
Osteoporosis & $2(\% 3,3)$ & $7(\% 7,0)$ \\
Goitre & - & $4(\% 4,0)$ \\
Anemia & $2(\% 3,3)$ & $2(\% 2,0)$ \\
Others & $4(\% 6,7)$ & $2(\% 2,0)$ \\
\hline $\begin{array}{l}\text { RA: Rheumatoid arthritis; AS: Ankylosing spondylitis; HT: Hypertension; DM: Diabetes Mellitus; HPL: } \\
\text { Hyperlipidemia. Table 2 presents the distribution of co-morbid diseases as percentages and number } \\
\text { of cases in both groups. }\end{array}$ &
\end{tabular}

\section{Clinical Activity Scores}

When we compared DAS28 and VAS scores in RA patients before and after Anti-TNF alfa treatment, we found significant difference between them $(p<0.001)$. Mean DAS28 value was 6.8 before Anti-TNF alfa treatment which decreased to 6 after Anti-TNF alfa treatment. Mean VAS value was 9 before AntiTNF alfa treatment which decreased to 7 after Anti-TNF alfa treatment (Figure 1).

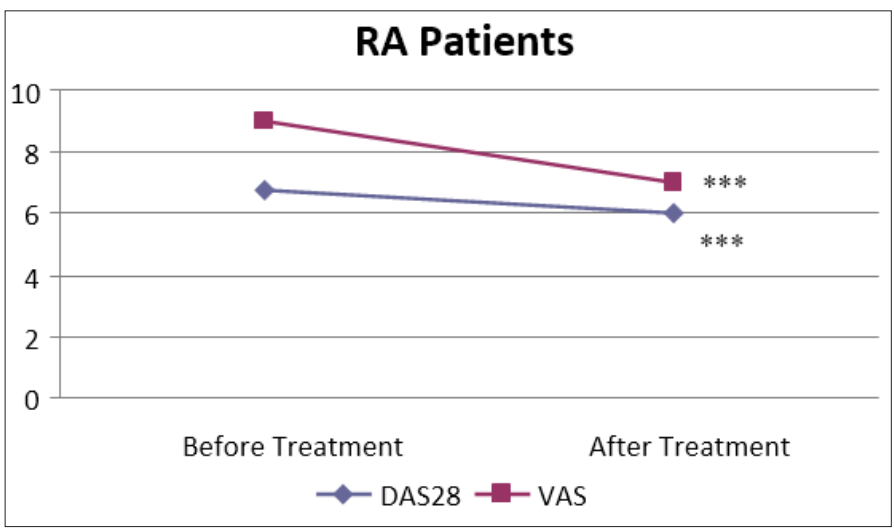

Figure 1. The comparison of DAS 28 and VAS values in patients with RA before and after Anti-TNF alfa treatment

$p<0,001$ before versus after Anti-TNF alfa treatment

Likewise, when we compared BASDAI and VAS scores in AS patients before and after Anti-TNF alfa treatment, we found significant difference between them $(p<0.001)$. BASDAI score decreased from 6.1 to 5.3 and VAS value decreased from 8 to 6 after Anti-TNF alfa treatment. BASDAI score decreased from 6.1 to 5.3 and VAS value decreased from 8 to 6 after treatment (Figure 2).

\section{Laboratory results}

CRP levels before and after Anti-TNF alfa treatment were presented in Table 3. A significant difference was observed between plasma CRP levels before and after Anti-TNF alfa treatment in both groups $(p<0.001)$. The mean measured CRP level of RA patients was $15.1 \mathrm{mg} / \mathrm{L}$ before Anti-TNF alfa treatment which was decreased to $5.1 \mathrm{mg} / \mathrm{L}$ after Anti-TNF alfa treatment (Figure 3). Accordingly, the mean alayzed CRP level of AS patients was decreased from $18.1 \mathrm{mg} / \mathrm{L}$ to $4.8 \mathrm{mg} / \mathrm{L}$ after the treatment (Figure 3).

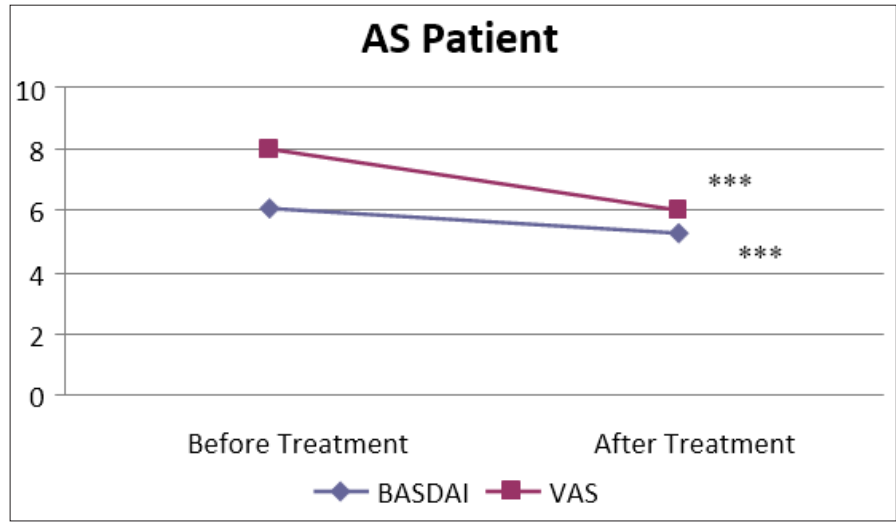

Figure 2. The comparison of BASDAI and VAS values in patients with AS before and after Anti-TNF alfa treatment

*** $p<0,001$ before versus after Anti-TNF alfa treatment

Tablo 3. Change in clinical and laboratory parameters before and after the Anti-TNF alfa treatment

\begin{tabular}{|cccc|}
\hline & $\begin{array}{c}\text { Before Anti-TNF } \\
\text { alfa treatment }\end{array}$ & $\begin{array}{c}\text { After Anti-TNF } \\
\text { alfa treatment }\end{array}$ & p-value \\
\hline MORNING STIFFNESS & & & \\
AS & $40(20-65)^{* * *}$ & $12,5(5-25)$ & $<0,001$ \\
RA & $45(20-60)^{* * *}$ & $15(5-60)$ & $<0,001$
\end{tabular}

VAS

$\begin{array}{llll}\text { AS } & 8(3-9)^{* * *} & 6(2-8) & <0,001 \\ \text { RA } & 9(6-10)^{* * *} & 7(4-9) & <0,001\end{array}$

ESR

AS $\quad 40,5(3-142) * * * \quad 21(2-63) \quad<0,001$

RA $\quad 46(5-110) * * * \quad 28,5(3-90) \quad<0,001$

CRP

AS $\quad 18,1(3,1-139)^{* * *} \quad 4,8(1,2-46) \quad<0,001$

RA $\quad 15,1(1,4-174) * * * \quad 5,1(1-91) \quad<0,001$

BASDAI

AS $\quad 6,1(4,0-7,5)^{* * *} \quad 5,3(3,1-6,8) \quad<0,001$

DAS 28

RA $\quad 6,8(5,2-8,2) * * * \quad 6,0(3,5-7,3) \quad<0,001$

AS: Ankylosing spondylitis; RA: Rheumatoid arthritis; VAS: Visual analogue scales; DAS28: Disease Activity Score 28; BASDAI: Bath Ankylosing Spondylitis Disease Activity Index; CRP: C-reactive
protein; ESR: Erythrocyte sedimentation rate; Significance levels are shown as * $p<0,05, * * 0<0,01$, protein; ESR: Erythrocyte sedimentation rate; Significance levels are shown as ${ }^{*} \mathrm{p}<0,05,{ }^{* *} \mathrm{p}<0,01$,
${ }_{* * *} \mathrm{p}<0,001$ when comparing ankylosing spondylitis patients and rheumatoid arthritis patients. Data are presented as mean and range (minimum-maximum).

Similarly, a statisticallly significant difference was found between ESR values before and after the Anti-TNF alfa treatment $(p<0.001)$. The avarage ESR values decreased from 46 to $28.5 \mathrm{~mm} / \mathrm{h}$ in RA patients and from 40.5 to 21 in AS patients after treatment (Table 3/Figure 4).

In addition, we have assessed the correlation between changes in BASDAI scores and age, age of disease diagnosis, duration of disease, change in ESR and CRP in RA group. There was no correlation between them (Table 4).

Furthermore, we have analysed the correlation between changes in DAS28 score and age, age of disease diagnosis, duration of disease, change in ESR and CRP in RA group. There was no correlation between them (Table 5). 


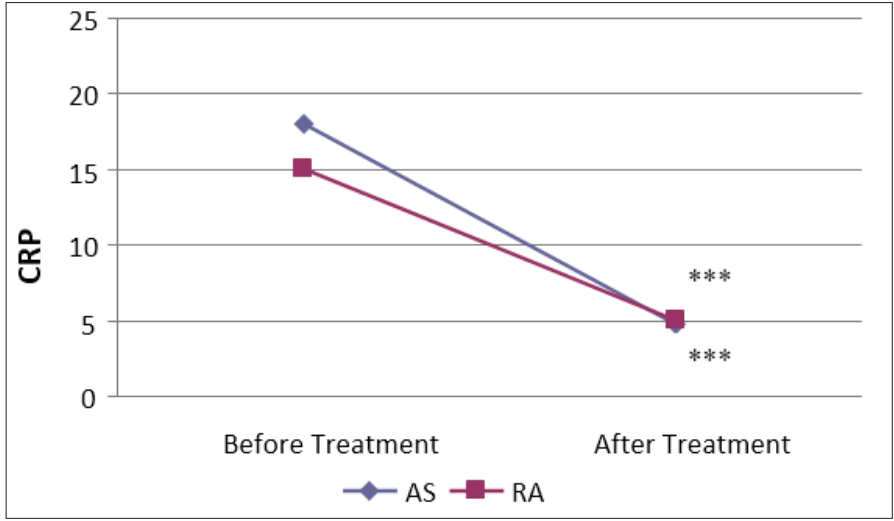

Figure 3. The comparison of serum CRP levels in patients with AS\&RA before and after Anti-TNF alfa treatment

**** $p<0,001$ before versus after Anti-TNF alfa treatment

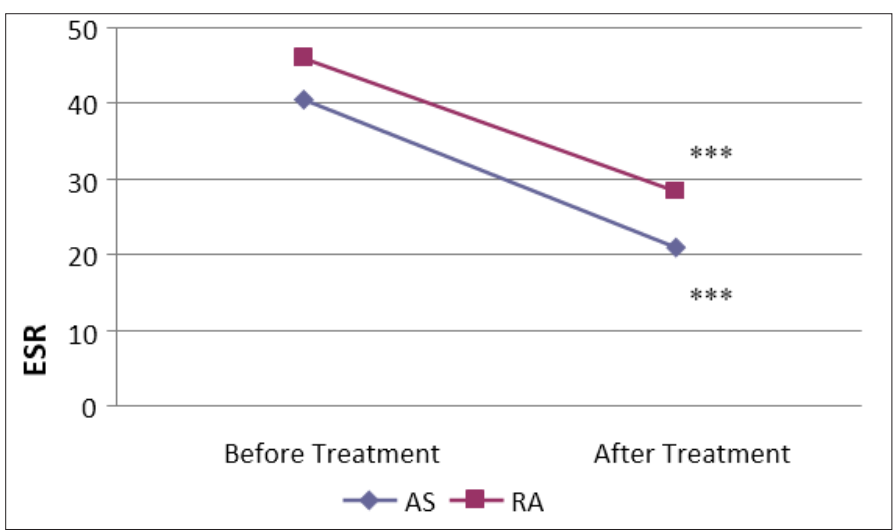

Figure 4. The comparison of ESRs in patients with AS\&RA before and after Anti-TNF alfa treatment

*** $p<0,001$ before versus after Anti-TNF alfa treatment

Table 4. Correlations among the change in BASDAl score and Age, Age of Disease Diagnosis, Duration of Disease, Change in ESR and CRP value in AS Group

\begin{tabular}{|lcc|}
\hline & Correlation Coefficient & p-value \\
\hline Age & 0,017 & 0,899 \\
Age of Disease Diagnosis & 0,025 & 0,85 \\
Duration of Disease & $-0,016$ & 0,906 \\
Change in ESR & $-0,054$ & 0,684 \\
Change in CRP & 0,086 & 0,512 \\
\hline
\end{tabular}

AS: Ankylosing spondylitis; CRP: C-reactive protein; ESR: Erythrocyte sedimentation rate. Significance levels are shown as ${ }^{*} p<0,05,{ }^{* *} p<0,01,{ }^{* * *} p<0,001$.

Table 5. Correlations among the change in DAS28 score, and Age, Age at Disease Diagnosis, Duration of Disease, Change in ESR and CRP values in the RA Group

\begin{tabular}{|lcc|}
\hline & Correlation Coefficient & p-value \\
\hline Age & $-0,059$ & 0,563 \\
Age of Disease Diagnosis & $-0,060$ & 0,555 \\
Duration of Disease & $-0,087$ & 0,387 \\
Change in ESR & 0,132 & 0,192 \\
Change in CRP & 0,036 & 0,723 \\
\hline $\begin{array}{l}\text { RA: Rheumatoid arthritis; CRP: C-reactive protein; ESR: Erythrocyte sedimentation rate. Significance } \\
\text { levels are shown as * } \mathrm{p}<0,05,{ }^{* *} p<0,01,{ }^{* * *} p<0,001 .\end{array}$ \\
\hline
\end{tabular}

Also, we have evaluated the Anti-TNF alfa treatment according to the gender and smoking history of patients, whether those parameters have an impact on the treatment. We have found out that there was no correlation between changes in BASDAI score after treatment in AS patients, as well there was no correlation between changes in DAS28 score in RA patients (Table 6).

Table 6. According to Gender and Smoking History Change in DAS28 within RA Group, and Change in BASDAI within AS Group

\begin{tabular}{|c|c|c|}
\hline & $\begin{array}{c}\text { AS } \\
\text { BASDAI }\end{array}$ & $\begin{array}{c}\text { RA } \\
\text { DAS28 }\end{array}$ \\
\hline \multicolumn{3}{|l|}{ Gender } \\
\hline Female & $-0,7(-3,1--0,2)$ & $-0,8(-1,9-1,3)$ \\
\hline Male & $-0,8(-2,0--0,4)$ & $-0,8(-2,6-0,1)$ \\
\hline$p$-value & 0,841 & 0,941 \\
\hline \multicolumn{3}{|l|}{ Smoking history } \\
\hline Nonsmoker & $-0,7(-2,0--0,4)$ & $-0,8(-2,6-1,3)$ \\
\hline Smoker & $-0,7(-3,1--0,2)$ & $-0,8(-2,0-0,1)$ \\
\hline$p$-value & 0,321 & 0,482 \\
\hline
\end{tabular}

\section{DISCUSSION}

In the present study, the efficacy and safety of Anti-TNF alfa treatment in 100 RA and 60 AS patients who are regularly monitorized in our clinic at least for six months period was investigated. Patients who received conventional treatment before the study (sulfasalazine ve NSAIDs) were established to display marked imporvement in clinical outcome and laboratory values following Anti-TNF alfa treatment. Side effects associated with Anti-TNF alfa treatment occurred at a lower rate than those reported in the literature. The most commonly encountered side effect was development of skin, soft tissues and joints infections. But, there was no serious infection. In patients included in the present study, substantial improvement was determined in pain, morning stiffness, and global evaluation of the patients and the physician after Anti-TNF alfa treatment. There was prominent decrease in BASDAI and DAS 28 scores, which are considered as disease activity indexes for AS and RA patients respectively. ESR and CRP values, which are laboratory parameters, were found to be markedly decreased. In the evaluation of demographic characteristics of the patients in the present study, it was established that younger and male patients are predominant in AS patients while female and elder patients are more common among RA patients.

AS typically occurs more commonly among male and younger patients. It has a more slowly progressing insidious course and presents mostly with peripheral joint involvement with a milder spinal ankylosis in women. Female/male ratio in AS has recently been reported to be varying between 1/10-1/3. $[14,15]$ In the present study, female/male ratio was found to be $4 / 11$, which is compatible with the literature. 
In a multicentered RA and AS study, conducted by Bodur et.al, it was reported that mean age of the patients was $38.1 \pm 10.6$ years, mean duration of disease was $11.5 \pm 7.9$ years and time from diagnosis was $8.9 \pm 6.4$ years. ${ }^{[16]}$ In the present study, mean age of AS patients taking Anti-TNF alfa treatment was 39.3 \pm 11.5 years and mean age when they were diagnosed with AS was $29.2 \pm 10.6$ years. Mean duration of disease in RA patients receiving Anti-TNF alfa treatment was 8.5 years (range:1-25 years), which was consistent with the literature.

Konttinen et.al investigated the efficacy of etanercept and infliximab treatment in 229 AS patients with a multicentered study and they have reported marked improvements in pain, morning stiffness, BASDAl, sedimentation and CRP values at the end of two years follow up. Moreover, they have reported $79 \%$ and $42 \%$ improvement according to the ASAS20 and ASAS40 criterias, respectively. ${ }^{[17]}$ Consistent with this literature, a statistically significant clinical and biochemial positive treatment response was determined in BASDAI, VAS, CRP and ESR evaluation results of the patients after treatment in the present study $(p<0.001)$.

In the multi centered double-blind randomized placebo controlled study of Van der Heijde with 279 patients, (ASSERT), 201 patients were administered infliximab and 78 patients placebo. In the evaluation made 24 weeks later, BASDAI-50 response was obtained in $51 \%$ of the patients in infliximab groups and $10.7 \%$ of those in placebo group. Improvement in BASFI was seen in $47.5 \%$ of patients in infliximab group, while it improved in $13.3 \%$, of those in placebo group. In adition, it was reported that in infliximab group, ASAS-20 response, ASAS 5/6 response and ASAS partial remissson response was obtained in $61.2 \%, 49 \%$ and $22.4 \%$ of patients respectively. ${ }^{[18]}$ The study of Van der Heijde et.al including 315 patients, in the eveluation made 24 weeks later, BASDAI response was obtained in $42.3 \%$ of the patients. ${ }^{[19]}$

Ferdinand et al. administered three different treatments i.e. adalimumab+methotrexate, only methotrexate and only adalimumab to 799 patients with active RA and followed them for two years. At the end of first year, DAS28 remission (DAS28<2.6) was obtained in $43 \%, 23 \%$ and $21 \%$ of patients in adalimubab+methotrexate, adalimubab and methotrexate groups, respectively. At the end of second year, remission was obtained in $49 \%$ of patients receiving combined treatment and $25 \%$ of those receiving adalimumab and methotrexate on their own. ${ }^{[20]}$ In our study, DAS28 remission was achieved at 24th weeks in patients receiving Anti-TNF alfa treatment. In the COMET study, 542 patients with active RA were administered methotrexate or etanercept+methotrexate and quality of life and disease activity scales were compared between the onset of treatment and at the end of second year. DAS28 remission (DAS<2.6) was obtained in 132 of $265(50 \%)$ patients receiving combined treatment, and in 73 of 263 patients (28\%) receiving only methotrexate. ${ }^{[2]}$ In this study, DAS28 remission (DAS28<2.6), was demonstrated in 7 of 37 (\%19) patients receiving Anti-TNF alfa treatment, and in 3 of 38 patients (8\%) receiving DMARDs treatment.
In the ATTRACT study, one group was administered infliximab+methotrexate and the other group only methotrexate. In the group not rmeeting AC20 criteria and using Anti-TNF alfa treatment, in DAS28, CRP, ESR, parameters measured at 54th week, marked improvement was observed compared to the groups receiving only methotrexate..$^{[22]}$

In the ARMADA study in which long term efficacy and the safety of the addition to adlimubab to methotrexate was investigated for 4 years in RA patients. In ARMADA study, after 4 years, DAS 28 score decreased from 5.3 to 3 , HAQ 20 score from 1.5 to 0.7 and CRP value from $25 \mathrm{mg} / \mathrm{L}$ to $7 \mathrm{mg} / \mathrm{L} .{ }^{[23]} \mathrm{In}$ our study, DAS28 score decreased from 6.8 to 6 and CRP value from $15.1 \mathrm{mg} / \mathrm{L}$ to $5.1 \mathrm{mg} / \mathrm{L}$.

The treatment of RA cases with Anti-TNF alfa drugs bring about marked decrease in disease activity and higher rates of remission compared to DMARDs treatment. Currently, Anti-TNF alfa drugs has various superior aspects compared to conventional DMARDs, positive response continues as long as drugs are used, but cost of treatment is very high. These are parameters that should be taken into account when choosing these drug, it should also be in mind that long term side effect profile of these drugs still remains uncertain and they may be associated with opportunistic infections like tuberculosis, which are especially important in our country. Clinicians should be vigilant for infections at infusion sides or intra articular, malignancies, autoimmunity and etc. while managing these patients.

In conclusion, our study is a population based cross-sectional study on the patients with RA and AS, and it evaluates the association between treatment modalities and their clinical/biochemical results. Our findings show that AntiTNF alfa treatment seems to be efficacious and safe on the patients with RA and AS. Our data showed a marked clinical/ biochemial progress in BASDAI, VAS, CRP and ESR values. But our study also highlights that these drugs should be carefully monitorized because of their severe side effects.

\section{ETHICAL DECLARATIONS}

Ethics Committee Approval: In this research, the data before 2020 was used and the research was concluded before 2020. According to the Regulation on Clinical Researches published in the Official Gazette of the Republic of Turkey with the number 28617 dated 3 November 2015, the ethics committee approval was not obtained in accordance with the article "Retrospective studies are outside the scope of the regulation (article 2- (2))". This study was prepared in accordance with the Law on Protection of Personal Data, by anonymizing patient data and in accordance with the 2013 Brazil revision of the Helsinki Declaration and guidelines for Good Clinical Practice..

Informed Consent: Because the study was designed retrospectively, no written informed consent form was obtained from patients.

Referee Evaluation Process: Externally peer-reviewed. 
Conflict of Interest Statement: The authors have no conflicts of interest to declare.

Financial Disclosure: The authors declared that this study has received no financial support.

Author Contributions: All of the authors declare that they have all participated in the design, execution, and analysis of the paper, and that they have approved the final version.

\section{REFERENCES}

1. Lee DM, Weinblatt ME. Rheumatoid arthritis. Lancet, 2001;358(9285):90311.

2. Braun J, Sieper J. Ankylosing Spondylitis. Lancet 2007;369:1379-90.

3. Scott DL, Kingsley GH. Tumor necrosis factor inhibitors for rheumatoid arthritis. N Engl J Med 2006;355 704-12.

4. Larché MJ, Sacre SM, Foxwell BM. Pathogenic role of TNFa in rheumatoid arthritis. Drug discovery today: Disease Mechanisms 2005;23 367-75.

5. Ehrenstein MR, Evans JG, Singh a, et al. Compromised function of regulatory t cells in rheumatoid arthritis and reversal by anti-TNF therapy. J Exp Med. 2004; 200: 277-285.

6. Taylor PC, Steuer A, Gruber J, et al. Comparison of ultrasonographi assessment of synovitis and joint vascularity with radiographic evaluation in a randomized, placebo-controlled study of infliximab therapy in early rheumatoid arthritis. Arthitis \& Rheumatism 2004;50:44-8.

7. Braun JJ, Xiang J, Brandt H, et al. Treatment of spondyloarthropathies with antibodies against tumour necrosis factor a first clinical and laboratory experiences. Ann Rheum Dis 2000;59:38-42

8. Sonel B, Tutkak H, Düzgün N. Serum levels of IL-1beta, TNF-alpha, IL-8, and acute phase proteins in seronegative spondyloarthropathies. Joint Bone Spine 2002;69.463-7.

9. Mansour M, Cheema GS, Naguwa SM, et al. Ankylosing spondylitis: a contemporary perspective on diagnosis and treatment. Semin Arthritis Rheum 2007;36:210-23.

10. Davis JC Jr. Understanding the role of tumor necrosis factor Inhibition in ankylosing spondylitis. Semin Arthritis Rheum 2004;34:668-77.

11. Woolley DE, Tetlow LC. Mast cell activation and its relation to proinflammatory cytokine production in the rheumatoid lesion. Arthritis Res 2000;2:65-74.

12. Gabriel SE. The epidemiology of rheumatoid arthritis. Rheum Dis Clin North Am 2001;27:269-81.

13. Padyukov L, Silva C, Stolt P, Alfredsson L, Klareskog L. A gene-environment interaction between smoking and shared epitope genes in HLA-DR provides a high risk of seropositive rheumatoid arthritis. Arthritis Rheum 2004;50:3085-92.

14. Mielants H, Veys EM, Goemaere S, Goethals K, Cuvelier C, De Vos M. Gut inflammation in the spondyloarthropathies: clinical, radiologic, biologic and genetic features in relation to the type of histology. a prospective study. J Rheumatol 1991;18(10):1542-51.

15. Will R, Edmunds L, Elswood J, Calin A. Is there sexual inequalty in ankylosing

16. spondylitis? A study of 498 women and 12002 men. J Rheumatol 1990;17:1649-52.

17. Bodur H, Ataman S, Akbulut L, et al. Characteristics and medical management of patients with rheumatoid arthritis and ankylosing spondylitis. Clin Rheumatol 2008;27:1119-25.

18. Konttinen L, Tuompo R, Uusitalo T, et al. Anti-TNF therapy in the treatment of ankylosing spondylitis: the Finnish experience. Clin Rheumatol 2007;26:1693-700.

19. Van der Heijde D, Dijkmans B, et al. Efficacy and safety of infliximab in patients with ankylosing spondylitis: results of a randomized, placebocontrolled trial (ASSERT). Arthritis Rheum 2005;52:582-91.
20. Van der Heijde D, Kivitz A, Schiff $M H$, et al. Efficacy and safety of adalimumab in patients with ankylosing spondylitis: results of a multicenter, randomized, double-blind, placebo-controlled trial. Arthritis Rheum 2006;54:2136-46.

21. Breedveld FC, Weisman MH, Kavanaugh AF, et al. The PREMIER study: A multicenter, randomized, double-blind clinical trial of combination therapy with adalimumab plus methotrexate versus methotrexate alone or adalimumab alone in patients with early, aggressive rheumatoid arthritis who had not had previous methotrexate treatment. Arthritis Rheum 2006;54(1):26-37.

22. Emery P, Breedveld FC, Hall S, et al. Comparison of methotrexate monotherapy with a combination of methotrexate and etanercept in active, early, moderate to severe rheumatoid arthritis (COMET): a randomised, double-blind, parallel treatment trial. Lancet 2008;2;372(9636):375-82.

23. Smolen JS, Han C, Bala M, et al. ATTRACT Study Group. Evidence of radiographic benefit of treatment with infliximab plus methotrexate in rheumatoid arthritis patients who had no clinical improvement: a detailed subanalysis of data from the anti-tumor necrosis factor trial in rheumatoid arthritis with concomitant therapy study. Arthritis Rheum 2005;52(4):1020-30.

24. Weinblatt ME, Keystone EC, Furst DE, Kavanaugh AF, Chartash EK, Segurado OG. Long term efficacy and safety of adalimumab plus methotrexate in patients with rheumatoid arthritis: ARMADA 4 year extended study. Ann Rheum Dis 2006;65:753-9. 